\title{
Home, Not Alone
}

\author{
Chantal Degril
}

\author{
Psychotherapist, Central Otago
}

\section{Abstract}

The notion of "home" evokes something familiar but also, as Freud beautifully demonstrated, it evokes the uncanny. This notion is examined using the example of a case of phobia, a structure which convokes an object as, not so much a source of anxiety, rather a protection against it. The work of Jacques Lacan on "object relations" serves as the main reference for discussion of the case material.

Ko te ariā "kāinga", he whakaarahanga mea e taunga ana, heoi anō hoki, ki tā Freud whakaahuatanga tau, he whakaarahanga tipua kē. Ka whakamātauhia tēnei aria i raro i te tauiratanga mai o te whakaaturanga āhua o "wehi”, he anga whakaputanga hau, ehara nei I te whakaputanga anipā, engari ia he pākatitanga kē atu. Ko ngā mahi "hononga pae” a Jacques Lacan te ariā whakapae matua hai tohutoro matapakitanga o te kohinga korero.

Keywords: uncanny; anxiety; unconscious; phobia; Other; Freud; Lacan; object; object relations; case study

\section{Introduction}

The idea of presenting this paper came to mind after reading the title of this year's conference: "Home is Where we Start From". The title raised in me some thoughts about the notion of home, which is sometimes the place where one finds peace, solace and security. However, home is also a place of conflicted relationships, sometimes of secrets or of difficult truths about the family history, with all their implications on one's personal life, whether they are conscious or unconscious ones.

The theme of home also evoked in me Freud's (1919/1925) famous paper, "The Uncanny" - "das Unheimliche" which translates from the German as unhomely, an ambivalent notion which I use here to examine the notion of "home". The uncanny has a correlate: anxiety. Something appears uncanny when it is at the articulation between the familiar and the unfamiliar and anxiety is the affect that accompanies it.

One could say the uncanny is part of everyone's experience and, more precisely, of everyone's unconscious. In a way, it is part of everyone's homeliness, if we consider the formations of the unconscious as very homely, indeed. As I think the uncanny is par-

Degril, C. (2012). Home, not alone. Ata: Journal of Psychotherapy Aotearoa New Zealand, 16(1), 43-50. DOI: 10.9791/ajpanz.2012.06. Copyright @ 2012 New Zealand Journal of Psychotherapists Inc. 
ticularly but not exclusively illustrative of the structure of phobia, I use the case of a ten year old phobic boy in order to discuss the status of the uncanny and anxiety in this particular structure. I use these concepts from both a Freudian and a Lacanian perspective.

\section{Freud's Research on the "Uncanny"}

In his remarkable paper on the uncanny, Freud (1919/1925) examined at length the meaning of the word "heimlich" and discovered it had a double meaning. The first series of meanings relates to: quiet, lovely, gay, cheerful, intimate, and comfortable. The second series of meanings refers to something that is concealed, kept from sight, withheld from others. To do something heimlich means to do something behind someone's back. To behave heimlich is to behave as though there was something to conceal, for example, as in a heimliche love affair. In that context, heimliche carries undertones of gruesome: everything that ought to have remained secret and hidden but has come to light. Freud concluded that heimlich is a word whose meaning develops in the direction of ambivalence, until it finally coincides with its opposite, unheimlich. In that way, heimlich and unheimlich are the two sides of the same coin.

In his study of the uncanny, Freud (1919/1925) took the concept a bit further and came to identify the "Un" of Unheimlich with repression: "It may be true that the uncanny is something which is secretly familiar [heimlich-heimisch], which has undergone repression and then returned from it" (p. 245). In this sense the uncanny is a form of anxiety: the uncanny and anxiety go hand in hand. For Freud, anxiety is thus the by-product of the failed repression of an element that is both familiar and unfamiliar and returns in the real, almost with a vengeance, a notion to which I return in my case study.

\section{Phobia and the Uncanny}

As illustrated in Freud's (1895/1909) famous case study of "Little Hans", a phobia is manifested by the presence of an object, constructed by the child as a phobic object. For "Little Hans", the phobic object was a horse. The child fears the object and, at the same time, he makes it omnipresent in his mind and in his life by anticipating its appearance, with fear and anxiety. Freud described anxiety in phobia as evolving from primary anxiety, which is part of the child's early experience and is related to his state of vulnerability and dependency, to a kind of anxiety that fixes itself on a phobic object. The latter, he said, functions as a screen, a protective barrier against anxiety itself. It is not the trigger for anxiety, it is a protection against it, hence the importance of treating this symptom with caution in the treatment of phobia.

What is this primary anxiety about? Freud says it concerns a previous pleasure, related to the mother, which is transformed into anxiety when a first repression has taken place.

Lacan took up the task of examining Freud's (1895/1909) case of "Little Hans" in his own seminar dedicated to The Object Relation (Lacan, 1994). Drawing on Freud's work on the object, and particularly the phobic object, Lacan critiqued object relations theory and presented the status of the object in psychoanalysis as lacking, as distinct from an object that comes to unify the subject or even to unite mother and child in a supposed dyad. 
Lacan's concept of the object as lacking, which he called "object a”, was based upon Freud's remark that the finding of an object is always the re-finding of it. The (re-found) object is therefore never that; moreover, it is always unsatisfactory as it never coincides with the lost object, and is never fully adapted to the subject's desire. By the fact it is lost, object a is the cause of desire. There is a gap between the object of satisfaction (or of need) and the object of desire. Lacan naturally considers the object in relation to the notions of "other" and "Other", two terms that ought to be distinguished as they belong to two different registers, a point I develop in the next section.

\section{Lacan's Theory of Object Relations}

Lacan's view on object relations is based on the concept that the object is lacking, drawing on Freud's thesis on sexuality according to which the "finding" of an object is always the "re-finding" of it. Lacan also distinguishes between three different kinds of lack, according to the three registers, which are interconnected or "knotted" together, of the "imaginary", the "symbolic" and the "real". Frustration, castration and privation are three ways of lacking the object. For example, if the lack is imaginary, the subject will perceive it as an injury, giving place to endless demands and claims, based on frustration as in the case of weaning, or the loss of the breast. Castration implies a symbolic lack and is linked to the law of prohibition of incest. Privation refers to a real lack, a real absence.

The child is in the hands of an other, usually the mother, upon whom he entirely depends for his survival. When the situation proceeds more or less satisfactorily, the sense of pleasure, of "homeliness" in a positive way, prevails, sometimes giving both mother and child an imaginary sense of wholeness. The mother is the other who mirrors the child and gives (in this case) him a sense of completeness. However, rather sooner than later, the child discovers that he is not everything to his mother. She comes and goes, leaves him and comes back. As a corollary, she is perceived as omnipotent: she can give or withhold, she can be present or not. The child realises that she desires something other than him, she desires elsewhere. Lacan developed the idea that the child experiences anxiety in that moment, when he sees his mother as lacking. This coincides with the construct of an Other, as a symbolic entity. In Lacan's theory, the "Other" is distinguished from the "other". The latter is of the order of the imaginary, it is the counterpart (counter part), the same as me, whereas, in Lacan's work, the Other is not only the m(Other) but also the symbolic order itself, the reservoir of all the signifiers that give the child a precise place, by naming him and by giving him precise attributes, as in "naughty boy" or "good boy". The mother, who provides bodily care, does so whilst pronouncing signifiers that the child appropriates for himself as "master signifiers" and with which he will identify.

The first repression concerns the discovery that the Other lacks. The child wonders about his mother: if she is lacking, what does she want of me? The desire of the Other is experienced as dangerous because it places the child in a position of an - the - object of desire, desire which is also enigmatic and raises anxiety. This anxiety is often, if not always, expressed in the analyses of children and of adults. In other words, from the moment the mother is experienced as castrated, as not whole - Lacan conceptualised this as not having the phallus - the child's position is to try and fill her gap by being her 
object. Lacan calls this process "alienation", a process by which a subject is constituted in the field of the Other, in the field of the symbolic, of the signifiers that he will receive and also by which he will be constituted.

As a solution to alienation, separation must take place, however, this operation involves another element, towards which mother and child can direct their desire: the father. In Lacan's terminology, "the father" is not necessarily the genitor, he may be someone else or a woman. It is a metaphorical and, hence, a symbolic operation, that Lacan called the "Name of the Father". It is the symbolic father who indicates to the mother that this child is not to be reintegrated, that is, he is not to fill her gap. The symbolic father relieves the child from having to fill the mother's lack, and allows the child to develop a desire of his own. When this operation is not efficient enough as in most cases of neuroses or, when it fails completely as in the case of psychoses, the barrier between the child and his mother's desire is deficient or non existent.

What follows is the presentation of a clinical situation which illustrates how the uncanny and its correlate, anxiety, which are very common parts of human experience, can take a particular place in a phobic subject, discussing the case material with reference to these Lacanian concepts.

\section{Case Study}

This is the case of a phobia in a ten year old boy. The boy had been referred because he refused to attend school and he had stayed at home for most of the school term. Several agencies had tried to facilitate the boy's return to school but the situation had deteriorated. Not only had he refused to go to school but he had also refused to go out at all. Some of the case workers involved were of the opinion that his mother spoiled her child and thought the cause of the problem was that he did what he wanted at home, such as watching TV and playing games at any time of day and night.

The boy was the only child of a couple who had separated when he was only one year old. He was conceived as a complete surprise, since his mother had been told as a young woman that she could not have children, as a consequence of serious health problems. The child's father was also an only child and remained very close to his own mother, even after his marriage. The marriage worked more or less well until the pregnancy. The boy's father became verbally abusive towards his wife and asked her to terminate the pregnancy. The wife decided to keep the baby and to leave the marriage; and she remained single until the boy reached school age. She had a few relationships which did not last. She claimed the boy's father was never interested in his child and that he was very inconsistent with his visits and, as a result, she found the child was confused, so she had stopped all contact between father and child.

I was told the child had just resumed seeing his father. This was instigated by the mother, who needed some "respite" as the mother put it, now that her child was constantly with her at home. She and the workers involved thought that this renewed contact could be the source of the child's anxiety.

When I saw the child and his mother for the first time, she explained her child had been bullied at school and the school staff had failed to protect the boy. She was desperate to find 
a solution and expected me to achieve what the others had failed at: change her child's behaviour and convince him to go back to school. While she was telling me this, her child sat, visibly unhappy to be in the room, and refusing to make eye contact with me. After a while, I asked the child and his mother whether I could see the child alone, about which they seemed surprised. The child begged his mother not to go out. I assured him that his mother would stay outside and that he could call her if he found the situation too unbearable. He finally accepted that he would stay in the room but continued to avoid eye contact and he remained mute. After a while he began to answer my questions by nodding (indicating "Yes") or shaking his head (indicating "No") as I tried to guess what was bothering him. He seemed to feel safe enough after a while and he finally admitted a fear of going crazy.

He explained that a few weeks prior to his refusal to go to school, he had been bothered by two boys who teased him about his ways and his physical appearance. They called him names, including some that referred to his sexual identity and the fact he was overweight. I figured out later that he was seen as being odd and "girly". He grew to hate these boys to the point of wishing them dead. Around that time, he had a dream, or, rather, a nightmare, in which a character, half human, half robot, a frightening figure in any case, chased him with the intention of killing him. I asked him to draw a picture of the character in question, which he did. It was indeed a terrifying picture, of a robot-like man, with scars and blood all over its face and body. He continued by saying this character was omnipresent in his mind and also he thought in reality, especially when he went outside the home. I concluded he was hallucinating this imaginary figure, a kind of monster, and that he felt safe only at home and with his mother. He also revealed that he did not want to go to school for fear of seeing the boys who bullied him. He thought his death wish could materialise and they could die as a result.

I asked him if he wanted to let his mother know about all that. When his mother heard what was going on for him, she looked at me in disbelief and smiled, saying that he had a very vivid imagination and that he was having me on. She said he was sleeping in a room next to hers and their beds were separated only by a thin wall. She would certainly have heard him if he had had nightmares.

I concluded this was a case of phobia. After only a few sessions the boy resumed attending school which greatly pleased his mother. However the boy became increasingly hostile to her. He had developed bad habits, she thought, after having spent so much time at home with her.

At this time, the boy began to refuse to attend our sessions and, as the tension at home became unbearable, I agreed to visit them at their house. The boy was happy enough to show me his room and his Xbox, which he used until late at night. When I arrived, he was frantically pushing some buttons on the controller. The main character of the game had a vivid resemblance to the picture of the monster he had drawn during our first session. He explained the character was a loner who was pursued to be killed and his aim was to survive all sorts of dangers. The boy hardly looked at me while playing, however I engaged him in a conversation about "imagination", a signifier his mother had used repeatedly to describe him: he had a lot of it, she said, even "too much!" He claimed imagination was much better than reality, which he did not like because it was too difficult to bear. $\mathrm{He}$ 
referred with sadness to the bullies at school and the friends who did not help him when he was in difficulty.

During the course of further sessions, he spoke about spending a lot of time watching horror series on TV with his mother which the two discussed the content of with a mixture of pleasure and fear.

The boy had started seeing his father more regularly and the mother was enjoying having more time by herself. Around that period, I learned that the mother had met a new partner, and this coincided with the start of the boy's difficulties. The boy did not appreciate the presence of this new man in their lives. As the mother increased her visits to him and vice versa, the boy became very aggressive. One day she called me in despair, saying she had to call the police after her son assaulted her new boyfriend. I expressed my surprise: how could a ten year old not be restrained by the adults around? She said she was scared of her son, who was becoming stronger. When I saw the boy after the incident, he was still fuming. He had attacked his mother's boyfriend after seeing him kiss his mother. He swore he would tear the man's lips out if it happened again. He saw himself as his mother's "bodyguard" and would make sure she would not be approached by her boyfriend. I commented on the fact his mother must have liked to be kissed by her boyfriend.

The mother joined the session later and engaged in an ambiguous discourse that revealed her ambivalent position in relation to her son: "You know you are number one in my life and you'll always be", she said to him, "It's not because I have a boyfriend that I don't love you anymore." This indicated that she was thus both fostering and prohibiting her son's incestuous fantasy. I intervened by saying that the love a woman has for a man is not of the same in nature as the love a mother has for her son. She did not register this and she continued claiming that "It is my right to have a life", as though she was trying to convince herself of it, as lost as her child was with regards to sexual desire. To this I replied "Nobody can deny you that, especially not your son."

Although she carried on seeing this man, often unbeknown to her son in order to avoid another crisis, she was still waiting for her son's approval to have a lover, leaving to her child the task of being his mother's bodyguard and, being prohibited to be there, all at the same time. In doing so, the child was in the impossible position of maintaining the dualism of the mother-child relationship while at the same time confronting his mother's desire for another beyond their relationship.

\section{Case Discussion}

There was no efficient barrier to protect this boy from his mother's desire; he was in the position of being her object, as long as no man in her life could fulfil her lack. The child was put in the place of occupying this position, knowing however that he was not enough to satisfy her fully. Being her bodyguard was a way of remaining his mother's object or, rather, an obstacle between her and an object other than himself. With the illusion that he was able to fulfil this function for his mother, he saw himself as omnipotent, as able to kill with his thoughts, a very intimate wish and a terrifying perspective at the same time.

At an age where a child is in the process of coming into being as a sexual subject, he sees himself in an imaginary way as being not castrated. The boys who bullied him at 
school however pointed at his castration, by using terms such as "girly", indicating his oddness, his inability to fit in among the other boys. It is also to be noted that his omnipotence mirrored that of his mother. She is the one who decides where he should fit, sometimes with her, as her object-phallus, sometimes away from her. Her ambivalent discourse does not enable her son to know where his place is with her, whether he is the unique object of her desire or the love-object she can give up. However, the boy "knows" that his mother is castrated, and that he is too. He is left in the lurch as to his own desire, by a father who cannot position himself in a symbolic way. His father did not have the desire to be a father and, even when he tried to be present, it was without much conviction. Furthermore, the mother indicated to the boy that she did not have any respect for his father: she saw him as weak and impotent, incapable of caring.

The phobia started around the time the mother met a potential partner, an indication that she was seeking a more adapted object than her child. Through his phobia the child thus registered his "inadequacy" or his castration, the repression of which could not take place. His nightmare about the monstrous character, and its subsequent "hallucination" and omnipresence in the child's imagination revealed an unconscious attempt at repression which, however, failed. The character became a phobic object. The phobic anxiety arose as a reminder of an interdiction, a bar, between him and his mother. As it is the case when the symbolic operation of the Name of the Father fails to position the subject at the "right" place in the Oedipus complex, through the prohibition of incest, the interdiction takes the form of an implacable, sadistic and cruel super ego. The uncanny in this case appears as an imaginary fearful figure, that is loosely knotted with the symbolic and the real. As the child himself said, he did not want to know too much about, not only the realities of life, but also the real as such, which, for Lacan, is a register referring to irremediable loss through repression. The child's anxiety stems from the fact he is too close to his object, his mother, without the mediation of the symbolic order to help him orient his desire outside his mother's desire. As such, the uncanny, or the frightening character, is linked with the mother's castration, in her changing position between omnipotence and impotence, appearing sometimes as having the phallus and sometimes lacking it. Without the symbolic order (the Name of the Father) to mediate between the child and his mother, the uncanny figure of the monster appears to give body to the question of the mother's castration, leaving the child without a direction as to his position in relation to his own desire, whether she has the phallus or not.

\section{Conclusion}

Home is where we start from, for the better and the worse. What is most homely, as Freud has demonstrated, is what is most intimate, most ancient and, at the same time, most uncanny and a source of anxiety. It constitutes one's most intimate truth.In psychoanalysis, and particularly Lacanian analysis, the work is about addressing the unconscious scene which is at play for each subject, in a unique way, not only between mother and child, not only from a historical, developmental perspective, but in what is unconsciously reconstituted in thought (Lacan 1953/2006), and produces symptoms. The case material I have presented on a phobia, illustrates how the symptom in its relationship to the 
unconscious scene, represents the truth of the family couple. On this basis, Lacan (1986/1990) proposed that the symptom (in this case the phobia) is:

The symptom which is the fundamental fact of analytic experience, [which] in this context defined as the representative of truth.

The symptom may represent the truth of the family couple. This is the most complex case, but also the one that is most open to our intervention....

The function of residue that the conjugal family sustains (and by the same stroke maintains) in the evolution of societies emphasises what is irreducible in a transmission-which is of another order than that of life according to the satisfaction of needs-but which is of a subjective constitution, implicating the relation with a desire that is not anonymous.

It is according to such a necessity that the functions of the mother and of the father are to be judged. That of the mother: in so far as her needs bear the mark of a particularised interest, even should this be so by the path of her own lacks. That of the father: in so far as his name is the vector of an incarnation of the Law in desire. (pp. $7-8$ )

\section{References}

Freud, S. (1909) Analysis of a phobia in a five-year-old boy ("Little Hans"). In The standard edition of the complete psychological works of Sigmund Freud (Vol.10, pp.1-150; J. Strachey, Ed. and Trans.). London, UK: Hogarth Press. (Original work published 1895)

Freud, S. (1925). The uncanny. In The standard edition of the complete psychological works of Sigmund Freud (Vol. 17, pp. 217-256; J. Strachey, Ed. and Trans.). London, UK: Hogarth Press. (Original work published 1919)

Lacan, J. (1990). Note on the child (R. Grigg, Trans.). Analysis, 2. (Original work published 1986) Lacan, J. (1994). Le séminaire, Livre IV (1956-1957): La relation d'objet [The seminar, Book IV (1956-1957): The object relation] (J-A. Miller, Ed.). Paris, France: Seuil.

Lacan, J. (2006). The function of speech and language in psychoanalysis. In Écrits: The first complete edition in English (pp. 237-268; B. Fink, Trans.). New York, NY: W. W. Norton. (Original work published 1953)

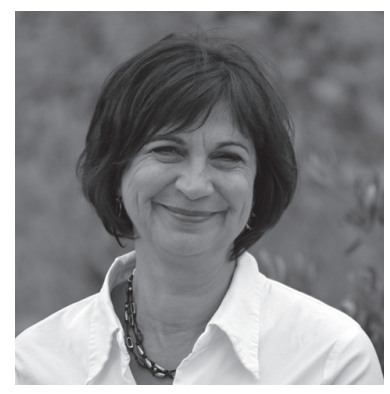

Chantal Degril has a PhD in psychology from the University of Aix-Marseille, France, and trained as a Lacanian psychoanalyst with the Australian Centre for Psychoanalysis (Melbourne). She works in private practice in Central Otago. Contact details: chantal@lindisriver.co.nz. 